\title{
A survey of the southernmost representatives of the tricolor species group, genus Phalotris (Serpentes, Colubridae)
}

\author{
Gerardo C. Leynaud ${ }^{1}$, Mario R. Cabrera ${ }^{2}$ and Paola Carrasco ${ }^{3}$ \\ 1 Centro de Zoología Aplicada, Universidad Nacional de Córdoba. Casilla de Correo 122, 5000 Córdoba, Argentina. \\ E-mail: gleynaud@efn.uncor.edu. \\ 2 CONICET Researcher - Departamento de Diversidad Biológica y Ecología, Universidad Nacional de Córdoba. Vélez \\ Sarsfield 299, 5000 Córdoba, Argentina. E-mail: mcabrera@efn.uncor.edu. \\ E-mail: azpao@yahoo.com.ar.
}

\begin{abstract}
A survey of the southernmost representatives of the tricolor species group, genus Phalotris (Serpentes, Colubridae). Colubrid snakes of the South American genus Phalotris are difficult to detect because of their secretive habits, and thus they are poorly represented in collections. The species Phalotris cuyanus and P. tricolor, the southernmost representatives of the tricolor species group, were studied to determine the limits of intraspecific variation of $P$. cuyanus and to consolidate the taxonomic relationship between both species, the phenetically and geographically closest members in the group. The distribution of selected external characters (cephalic, ventral and subcaudal scales), coloration pattern, width of white and black collars, and hemipenis morphology were analyzed. Comparative data on the other members of the group, $P$. mertensi and $P$. matogrossensis, are briefly discussed. Males of $P$. cuyanus have a higher number of ventral scales than males of P. tricolor (mean of 220.3 vs. 204.6). Cephalic melanism varies among individuals and does not have discriminant or geographic value for this species group. The white nuchal collar may partially cover the parietal scales in the four species. The black collar is moderately narrow in $P$. cuyanus, but it can be up to 12 scales wide in $P$. tricolor. Vertebral dotting is neither constant nor exclusive of any species. The four species of the group are well characterized by combinations of character states for each one. We suggest considering to $P$. cuyanus as an evolutionary species typical of the Monte biogeographic province.
\end{abstract}

Keywords: Serpentes, Colubridae, Phalotris cuyanus, Phalotris tricolor, biodiversity, South America.

\section{Introduction}

Ferrarezzi (1993) proposed the monophyly of the South American colubrid genus Phalotris

Received 16 February 2005.

Accepted 11 November 2005.

Distributed December 2005.
Cope and recognized three species groups within it: bilineatus, nasutus, and tricolor. The latter includes the species $P$. mertensi (Hoge), restricted to Brazil; P. tricolor (Duméril, Bibron and Duméril) distributed throughout Brazil, Paraguay, Bolivia and Argentina; P. matogrossensis Lema, D’Agostini and Cappellari, from Brazil and Paraguay (Lema et al. 2005), and $P$. 
cuyanus (Cei) present in the Argentine provinces of Mendoza and San Juan (Cei 1984, 1986, 1993, Leynaud and Bucher 1999). Despite their wide geographic distribution, snakes of this genus are difficult to detect because of their hypogeal and secretive habits (Lema 1984, Cei 1986, Cabrera 2004), and are poorly represented in collections.

The four species of the tricolor group share a common pattern consisting of incomplete postcephalic rings, forming a white collar behind the dark head and a black collar immediately behind the white one, followed by the ground color of body dorsum. Phalotris mertensi is easily distinguished from the other members of the group because of the black apex of each dorsal scale posterior to collars and because of its large body size: it can reach a total length of $1.5 \mathrm{~m}$, which doubles the maximum length of any other species in this group (Lema 1984, Cabrera 2004). Phalotris matogrossensis is distinguished by its white collar wider than the black one (Lema et al. 2005). On the contrary, the keys and descriptions available do not allow accurate separation of $P$. cuyanus from $P$. tricolor, because they are distinguished basically on the basis of the ground coloration of dorsum (observable only in living specimens).

Diagnosis of Phalotris cuyanus was based on two individuals, and it is known from very few specimens (Cei 1984, 1986, Avila et al. 1998, and the present work). On the other hand, the keys and descriptions available (Ferrarezi 1993, Lema et al. 2005) do not allow accurate separation of $P$. cuyanus from $P$. tricolor. The objective of this paper is to determine the limits of intraspecific variation of $P$. cuyanus, a rare snake endemic to Argentina, and to consolidate its taxonomic relationship with $P$. tricolor, the species of the group that is closest phenetically and geographically.

\section{Materials and Methods}

We studied 44 specimens of the tricolor group (see Appendix I); the sample comprised all the individuals available in the largest public collections of Argentina, including the holotype of Phalotris cuyanus and the holotype and three paratypes of $P$. punctatus (Lema 1979) (recently synonymized to $P$. tricolor by Lema et al. 2005, it was considered as a distinct species during our research). For comparative purposes we included also specimens of $P$. mertensi. Bibliographic data on the recently described $P$. matogrossensis were taken from Lema et al. (2005).

The variation of external morphological characters was analyzed (count of cephalic, ventral and subcaudal scales), as well as coloration pattern, and width (in number of scales) of black and white collars. For counting, the first wider than longer scale posterior to gulars was considered the first ventral, and the scale immediately anterior to the anal was considered the last ventral. The double subcaudal scales were counted on one side starting from the first pair in ventromedial postcloacal contact. The conical scale on the caudal tip was not included in the count. The width of the black and white collars is indicated as the number of scales with the respective color on the vertebral line. Where black or white colors covered part of scales it was indicated as “ $1 / 2$ ”, regardless of the area covered by the color (one third, a half or a greater area on the scale).

Sex was determined by both probing and counting the number of subcaudal scales in those individuals where it was not possible to examine gonads through dissection or by observing everted hemipenes. The hemipenes of at least one individual of each species were dissected longitudinally on the asulcate side and analyzed invaginated. Everting and agar-filling techniques, like those proposed by Manzani and Abe (1988) and Pesantes (1994) were unsuccessfully employed because of the small diameter and considerable length of the organ. Hemipenial terminology follows Peters (1964) and Zaher (1999).

Analyses of frequency distribution of characters as a function of latitude and longitude of the 
samples were performed by grouping the samples in three large areas of internal physiographic homogeneity, based on Cabrera and Willink (1980), Prado (1993), Cabrera (2001), and Alvarez et al. (2002): Eastern Humid Chaco + Misiones and part of Pantanal (A), Western Arid Chaco (B), and Monte (C) (Figure 1). Differences in number of scales of the nuchal collars and number of ventral scales between $P$. tricolor and $P$. cuyanus were analyzed through non-parametric tests (U- Mann-Whitney and Kruskal-Wallis). All statistical procedures were conducted using InfoStat 1.1. Significance level in all tests was established at $\alpha=0.05$.

\section{Results}

\section{Coloration Pattern}

In $70 \%$ ethanol Phalotris tricolor and $P$. cuyanus have a similar light brown or ochre coloration on the dorsum, which becomes a lighter shade of brown towards the flanks. In life, $P$. tricolor shows the same color or a definite orange or reddish tan (Figure 2; also in Leynaud and Bucher 2001). According to Cei $(1984,1986)$ the coloration of $P$. cuyanus in life is similar to that of $P$. tricolor, but lacking orange/red. However, we noted fading of red or another brilliant color a few months after fixation in formalin and permanent preservation in alcohol, turning light ochraceous the dorsum color (Figure 3). Discrimination based on coloration of preserved individuals becomes difficult also because $P$. tricolor and $P$. cuyanus may or may not exhibit small black dots scattered on the background color. Furthermore, both species may present incompletely black rostral and supralabial scales (compare Figures 2 and 3).

\section{Pholidosis}

A summary of variation in the selected characters between Phalotris cuyanus and $P$. tricolor is included in Table 1. Furthermore, the number of supralabials (six) is constant in the four species of the group ( $P$. cuyanus, $P$. mertensi, $P$. matogrossensis, and $P$. tricolor), with the second and third supralabials contacting to eye. In our samples, only one individual of $P$. tricolor (UNNEC 0176) has five supralabials on the left side, possibly as a result of fusion of scales 4 and 5. All specimens of $P$. cuyanus and $P$. tricolor revised have seven infralabials (as in P. matogrossensis, according to Lema et al. 2005), occasionally eight or, more rarely, six. All individuals of $P$. mertensi examined have eight infralabials. Temporal scales are in 1+1+2 arrangement in $P$. tricolor and $P$. cuyanus, except for cases of fusion or division.

For comparisons of ventral scale number only males were considered, since females of Phalotris cuyanus were not available in the sample. Ventral counts of male $P$. tricolor and $P$. cuyanus do not overlap ( $\mathrm{U}=3.25, \mathrm{P}=0.002$ ). The median in the former is 204.6 , with $75 \%$ of specimens at $209.5(\mathrm{~N}=11)$; in the latter species the median is 221.5, with $75 \%$ at $223(\mathrm{~N}$ $=6$ ). We evaluated if the higher number of ventrals in $P$. cuyanus would be evidenced also as a greater body length, so we transformed snout-vent length in percentage of the total length. The range for body length of $P$. cuyanus (90.3-91.9) falls within the variation range of $P$. tricolor (90.1-93.9), with similar means (91.2\% in the former and $91.4 \%$ in the latter).

The width of the nuchal collars, as represented by number of comprised scales, does not differ statistically between sexes (MannWhitney Test): $\mathrm{U}=140.5, \mathrm{P}=0.94 ; \mathrm{N}=19$ females and 17 males, for the white collar; and $\mathrm{U}=110, \mathrm{P}=0.259$ for the black collar, pooled all the samples of $P$. tricolor and $P$. cuyanus together. This result allowed us to group both sexes in subsequent analyses. When we considered the three subsamples A, B and C (Figure 1) Kruskal-Wallis test showed statistically significant differences in white collar width $(\mathrm{H}=$ 9.06; d.f. $=2 ; \mathrm{P}=0.011$ ) (sample size of areas: $A=5, B=24$, and $C=6$ ). Identification of the dissimilar group, or groups, through multiple comparison (Dunn's Method) revealed that 


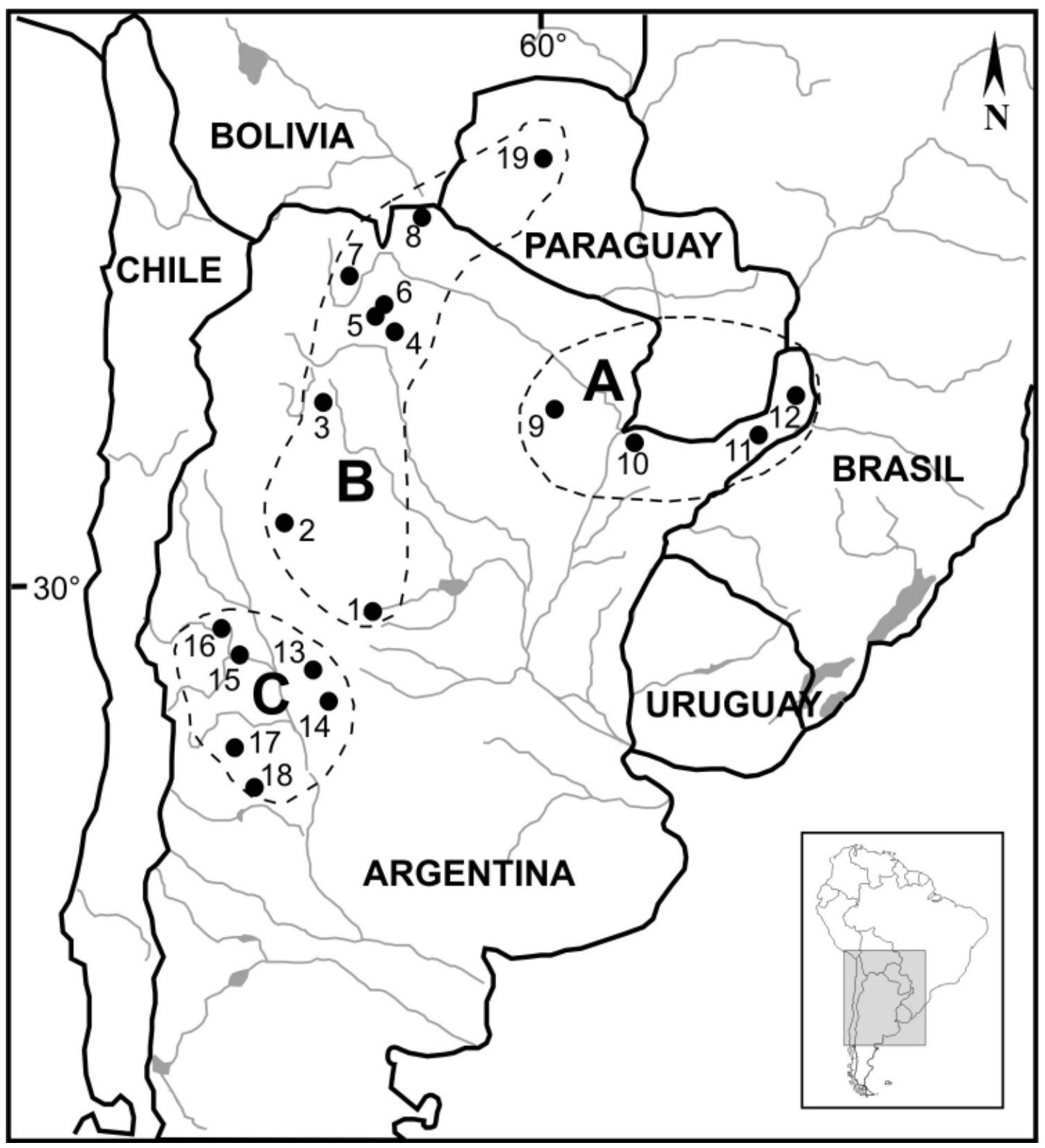

Figure 1 - Southern South American localities sampled for Phalotris tricolor (A - Humid Chaco + Misiones, B - Arid Chaco), and Phalotris cuyanus (C - Monte). Each dot may represent more than one specimen. 1: Córdoba; 2: Belén; 3: Rosario de la Frontera; 4: Finca Pozo largo; 5: Campo Grande (Salta); 6: Estación Biol. Los Colorados; 7: Yuto; 8: Misión La Paz; 9: Parque Nacional El Chaco; 10: Yacareí; 11: Campo Grande (Misiones); 12: Misiones province; 13: NW San Luis; 14: Campamento Seram; 15: Dique Bello; 16: Near Caucete (fide Cei 1986 - unverified); 17: Estancia Don Paco; 18: Los Reyunos; 19: Faro Moro. 


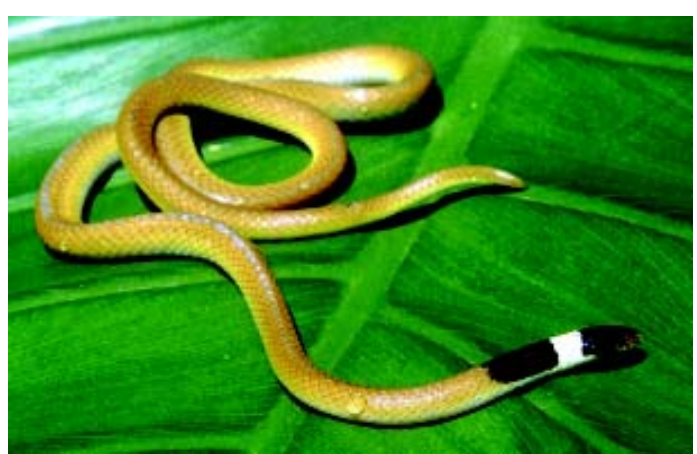

Figure 2. Phalotris tricolor (AC 419) in life. Note the light snout scales.

subsample $\mathrm{C}$ is different from both $\mathrm{A}$ and $\mathrm{B}$, whereas the latter two subsamples do not differ from each other. A similar result is observed in the number of scales determining black collar width $(\mathrm{H}=15.36$; d.f. $=2 ; \mathrm{P}=<0.001)$. Indeed, multiple comparison shows that subsample $\mathrm{C}$ is statistically different from $\mathrm{A}$ and $\mathrm{B}$, but these two subsamples are not different from each other.

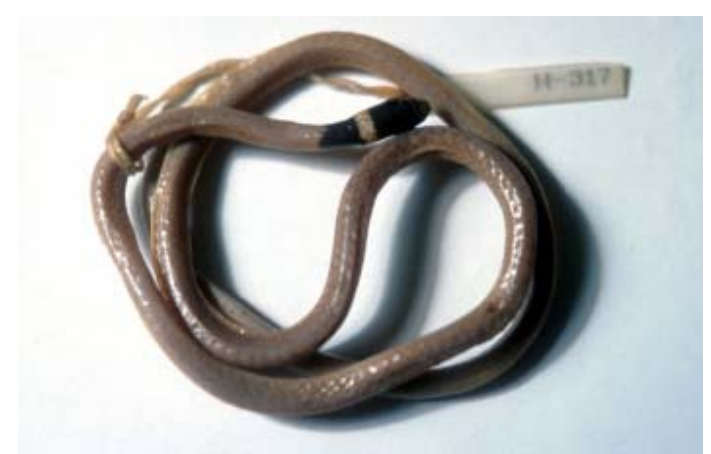

Figure 3 - The holotype of Phalotris cuyanus (MHNSR 317). Note scattered dotting on dorsum and faint dark vertebral line.

\section{Hemipenes}

Phalotris tricolor (CZA 0001) and $P$. cuyanus (MHNSR 1397) have in common thin and long hemipenes, extended in situ below 8-9 subcaudal scales, and longitudinal folds in the proximal portion of the hemipenial body, on its asulcate side. Both species have bilobed hemipenes, but show several interspecific diffe-

Table 1 - Variation in selected characters between the two southernmost species of the Phalotris tricolor group. Values represent range and mean \pm standard deviation (SD). Only males of $P$. cuyanus were available.

\begin{tabular}{|c|c|c|c|c|c|c|c|}
\hline \multirow[t]{2}{*}{ CHARACTERS } & \multicolumn{3}{|c|}{ Phalotris tricolor } & \multicolumn{4}{|c|}{ Phalotris cuyanus } \\
\hline & & $\bar{x} \pm S D$ & Range & $\mathrm{N}$ & $\bar{x} \pm S D$ & Range & $\mathrm{N}$ \\
\hline \multirow[t]{2}{*}{ Ventral scale counts } & $\sigma^{\pi}$ & $204.6 \pm 6.6$ & $192-215$ & 11 & $220.3 \pm 3.5$ & $216-224$ & 6 \\
\hline & ㅇ & $222.9 \pm 5.4$ & $216-237$ & 19 & & & \\
\hline \multirow[t]{2}{*}{ Subcaudal scale counts } & $\sigma^{\pi}$ & $30.2 \pm 1.5$ & $28-33$ & 11 & $32.3 \pm 1.0$ & $31-34$ & 6 \\
\hline & q & $23.8 \pm 1.6$ & $21-26$ & 20 & & & \\
\hline \multirow{2}{*}{ White nuchal collar width (scale counts) } & & $4 \pm 1.14$ & $1.5-6$ & 11 & $2.5 \pm 0.9$ & $1-3.5$ & 6 \\
\hline & ㅇ & $3.5 \pm 0.6$ & $2.5-4.5$ & 20 & & & \\
\hline \multirow[t]{2}{*}{ Black nuchal collar width (scale counts) } & $\sigma^{\pi}$ & $7 \pm 2.53$ & $4.5-12$ & 11 & $4.5 \pm 0.9$ & $3-6$ & 6 \\
\hline & q & $7 \pm 1.5$ & $4.5-10$ & 20 & & & \\
\hline \multirow[t]{2}{*}{ Snout-vent length (mm) } & $0^{x}$ & $303 \pm 62.9$ & $182-440$ & 11 & $291.6 \pm 86.5$ & $171-392$ & 6 \\
\hline & 우 & $303.1 \pm 122$ & $210-710$ & 19 & & & \\
\hline
\end{tabular}


rences: lobes in $P$. tricolor are $20 \%$ of total hemipenis length, with barely developed calyces on its entire surface. Lobes in $P$. cuyanus are $25 \%$ of total hemipenis length and, besides being relatively longer lobes, they exhibit largesized calyces in the proximal region and other less evident calyces at distal. The sulcus bifurcates in the middle of the hemipenis in P. tricolor, and closer to the tip in $P$. cuyanus, at the distal third of the organ. Spines in both species are present in the intrasulcate region and on the exterior sides of the bifurcated sulcus, but in $P$. tricolor they are arranged in longitudinal rows, whereas in $P$. cuyanus they are arranged in oblique rows. Spines in the latter species are noticeably thin and long.

\section{Discussion}

Both in the diagnosis of the original description of Phalotris cuyanus (Cei 1984) and in his book (1986), Cei highlights the size (“...relatively large...”; “...longer, with sharper tail..."- our translation) and the coloration without well defined lines in this species. He states that the white collar occupies three scales and that the melanistic one occupies " $4-5$ " scales (Cei 1986: 417). With a sample three times larger than the number of individuals known when the species was described, we can expand some of its diagnostic aspects.

Males of Phalotris cuyanus (females of this species were unavailable for comparisons) have a higher number of ventral scales than males of P. tricolor (220.3 vs. 204.6, respectively, for $75 \%$ of the samples). However, although $P$. cuyanus has more ventral scales, these may be smaller than in P. tricolor, and therefore do not determine greater body length in the former species with respect to its own total length. The cephalic melanism, which in some specimens ( $e$. $g$., in those of the type series of $P$. punctatus, now $P$. tricolor, see Appendix I) extends onto the gular region continuously or in spots, is a consequence of the interindividual variability and does not have discriminant nor geographic value.
The four species of the tricolor group ( $P$. cuyanus, $P$. matogrossensis, $P$. mertensi and $P$. tricolor) have in common two ventrally incomplete postcephalic rings, forming a white and a black collar. The width of the white nuchal collar in $P$. tricolor varies from six scales (UNNEC 0315) to only one and a half (FML 02309) in two extremes that we consider exceptional, as it generally has 3-4 scales in width. The white collar in $P$. cuyanus, like in $P$. mertensi, is 2-3 scales in width; one individual of $P$. cuyanus has only one scale (MACN exCENAI 3484). In these three species the white collar is narrower than the black collar or subequal in width. On the contrary, P. matogrossensis is easily distinguished from any other species in the group because its white collar is wider than the black one (Lema et al. 2005). The white nuchal collar may reach the posterior surface of the parietal scales in the four species of the group, making the white collar appear wider than the black collar onto the sides. The black collar on the vertebral scales is moderately narrow in Phalotris cuyanus (3-6 scales), $P$. mertensi (3-4 scales) and P. matogrossensis (5 scales; Lema et al. 2005). On the contrary, some specimens of $P$. tricolor have black collar of up to 12 scales in width, being usually more than six.

Vertebral dotting, occasionally forming a continuous line, is neither constant nor exclusive of any of the species of the group, not even for the formerly recognized $P$. punctatus. In the specimen MHNSR 1371 (P. cuyanus), for example, the dorsomedial scales of the white collar are longitudinally covered by a dark broken line. It also has a dark, barely evident vertebral line below the epidermis in dorsum and scattered melanistic dots, more noticeable in the anterior third of the body.

The four species of the tricolor group are relatively well characterized by particular combinations of character states for each species. Regarding to the two southernmost, closest species of the assemblage, Phalotris cuyanus can be considered an evolutionary species (sensu Frost and Hillis 1990) endemic to

\section{8}


a clearly defined region, the Monte biogeographic province (Cabrera 2001). The species was already known in the Argentine provinces of Mendoza and San Juan; we confirm here its presence in the province of San Luis, where it has not been cited before (Avila and Carrizo 2003) as vouchered by the specimens MACN (exCENAI) 1445 and MACN (exCENAI) 3484 (cited as P. tricolor by Lema et al. 2005). Phalotris tricolor has a wide distribution, ranging from Córdoba city, Argentina, as its southernmost locality, northwards to central Bolivia.

\section{Acknowledgements}

For the loan, exchange and/or access permits to inspect specimens under their care we are grateful to Juan C. Acosta (MCN-UNSJ), Beatriz Alvarez (UNNEC), Gustavo Carrizo (MACN), Francisco Franco (Instituto Butantan, São Paulo), Sonia Kretszchmar (FML), Humberto and Flavia Lagiglia (MHNSR), and Jorge Williams (MLP). Comments by Ronaldo Fernandes and one anonymous reviewer improved the manuscript. We thank B. McComb for her comments on the English style. Research was financially supported by Secretaría de Ciencia y Tecnología, Universidad Nacional de Córdoba (SeCyT-UNC), through grants to MRC (Resol. 62/03; 123/04 and 137/04).

\section{References}

Alvarez, B. B., R. A. Aguirre, J. A. Céspedez, A. B. Hernando, and M. E. Tedesco. 2002. Atlas de Anfibios y Reptiles de las Provincias de Corrientes, Chaco y Formosa, Argentina. I. Anuros, Cecílidos, Saurios, Anfisbénidos y Serpientes. Corrientes. EUDENE. 156 pp.

Avila, L. J. and G. R. Carrizo. 2003. Lista comentada y distribución geográfica de la herpetofauna de la provincia de San Luis, Argentina. Acta Zoologica Lilloana 47: 93-115.

Avila, L. J., J. C. Acosta and A. F. Murúa. 1998. Herpetofauna de la provincia de San Juan, Argentina: lista comentada y distribución geográfica. Cuadernos de Herpetología 12: 11-29.
Cabrera, A. L. and A. Willink. 1980. Biogeografía de América Latina. Washington. Secretaría Gral. OEA, Serie Biología; Monogr. 13; Second edition. 122 pp. +1 map.

Cabrera, M. R. 2001. Composición comparativa de la fauna de serpientes (Reptilia, Squamata) de cuatro provincias biogeográficas del Dominio Chaqueño. Revista del Museo Argentino de Ciencias Naturales, Nueva Serie 3: 109-118.

Cabrera, M. R. 2004. Las Serpientes de Argentina Central. Córdoba. Publicaciones UNC. 109 pp.

Cei, J. M. 1984. Una nueva especie de Elapomorphus de la región de Cuyo. (Colubridae, Serpentes). Boletín del Museo de Ciencias Naturales y Antropológicas "J. C. Moyano", Mendoza 4: 47-50.

Cei, J. M. 1986. Reptiles del centro, centro-oeste y sur de la Argentina. Museo Regionale di Scienze Naturali Torino, Monografia 4: 1-528.

Cei, J. M. 1993. Reptiles del noroeste, nordeste y este de la Argentina. Museo Regionale di Scienze Naturali Torino, Monografia 14: 1-949.

Ferrarezzi, H. 1993. Nota sobre o gênero Phalotris, com revisão do grupo nasutus e descrição de três novas espécies (Serpentes, Colubridae, Xenodontinae). Memórias do Instituto Butantan 55: 21-38.

Frost, D. R. and D. M. Hillis. 1990. Species in concept and practice: herpetological applications. Herpetologica 46: 87-104.

Lema, T. 1979. Elapomorphus punctatus, nova espécie de Colubridae para a Argentina (Ophidia). Revista Brasileira de Biologia 39: 835-853.

Lema, T. 1984. Sobre o gênero Elapomorphus Wiegmann, 1834 (Serpentes, Colubridae, Elapomorphinae). Iheringia, Série Zoologia 64: 53-86.

Lema, T. D., F. M. D’Agostini and L. H. Cappelari. 2005. Nova espécie de Phalotris, redescrição de P. tricolor e osteologia craniana (Serpentes, Elapomorphinae). Iheringia, Série Zoologia 95: 65-78.

Leynaud, G. and E. H. Bucher. 1999. La fauna de serpientes del chaco sudamericano: diversidad, distribución geográfica y estado de conservación. Academia Nacional de Ciencias, Miscelánea 98: 1-46.

Leynaud, G. and E. H. Bucher. 2001. Composition, relative abundance and activity patterns of the snake fauna of Los Colorados Biological Station (Western chaco of Argentina). Boletín de la Academia Nacional de Ciencias 66: 125-132.

Manzani, P. R. and A. S. Abe. 1988. Sobre dois novos métodos de preparo do hemipênis de serpentes. $M e$ mórias do Instituto Butantan 50: 15-20.

Pesantes, O. S. 1994. A method for preparing the hemipenis of preserved snakes. Journal of Herpetology 28: 93-95. 
Peters, J. A. 1964. Dictionary of Herpetology. New York. Hafner Publishing Co. 392 pp.

Prado, D. E. 1993. What is the Gran Chaco vegetation in South America? II. A redefinition. Contribution to the study of the flora and vegetation of the Chaco. VII. Candollea 48: 615-629.

Varela, E. A. 1999. Tipos de la colección herpetológica del Museo Argentino de Ciencias Naturales "Bernardino
Rivadavia”, Buenos Aires, Argentina. Iheringia, Série Zoologia 87: 57-74.

Zaher, H. 1999. Hemipenial morphology of the South American Xenodontine snakes, with a proposal for a monophyletic Xenodontinae and a reappraisal of Colubroid hemipenes. Bulletin of the American Museum of Natural History 240: 1-168.

\section{Appendix I - Specimens Examined}

Acronyms of the collections correspond to: Centro de Zoología Aplicada (CZA) and Cátedra de Anatomía Comparada (AC), both from the Universidad Nacional de Córdoba; Museo Argentino de Ciencias Naturales, Bs. As. (MACN and MACN-exCENAI) [Note: the acronym CHINM applied sometimes to this collection (e. g., Lema 1979) is equivalent to CENAI; the original numbers of the specimens were kept when they were incorporated to MACN (Varela 1999)]; Museo de La Plata (MLP); Museo de Ciencias Naturales de la Universidad Nacional de San Juan (MCN-UNSJ); Museo de Historia Natural de San Rafael, Mendoza (MHNSR); Universidad Nacional del Nordeste, Corrientes (UNNEC), and Fundación Miguel Lillo, Tucumán (FML), all from Argentina.

Phalotris cuyanus. ARGENTINA: Dique Bello, Dpto. 9 de Julio, San Juan, MCN-UNSJ 276; Los Reyunos, Dpto. San Rafael, Mendoza (holotype), MHNSR 317 (formerly numbered 300); Estancia Don Paco, Cochi-Có, Dpto. General Alvear, Mendoza, MHNSR 1371, 1397; NW San Luis, 80 km Capital, límite Mendoza, MACN (exCENAI 1445); Campamento Seram, Los Cerrillos, Dpto. La Capital, San Luis, MACN (exCENAI 3484).

Phalotris mertensi. BRAZIL: Estado de São Paulo, AC 433; Chácara Duas Águas, Botucatu, Estado de São Paulo, AC 434; Fazenda Santa Eliza, Campinas, Estado de São Paulo, AC 435; Pirassununga, Estado de São Paulo, AC 436; Avaré, Estado de São Paulo, AC 437; Bauru,
Estado de São Paulo, AC 438.

Phalotris tricolor. ARGENTINA: Dpto. Capital, Córdoba, AC 419; CZA 0001/0003, 0085, 0088, 111; Parque Nacional El Chaco, Dpto. Sargento Cabral, Chaco, CZA 087, UNNEC 5593; Rosario de la Frontera, Depto. Rosario de la Frontera, Salta, MLP.JW 935 [formerly MLPA 151; holotype of P. punctatus, it bears also a tag with the legend PARATYPUS; strangely enough, in the Figure 2 of Lema (1979, original description) this specimen has a tag different from any of the ones that it has now, since in the photograph the tag reads PARATIPO, even when it is the individual referred to as holotype in the text]; Estación Biológica Los Colorados, Dpto. Anta, Salta, CZA 125/131; Provincia de Salta, AC 448; Finca Pozo Largo, 12 km E Finca San Javier, 8 km S Joaquín V. González, Dpto. Anta, Salta, FML 02309, 02310; Campo Grande, Finca Los Colorados, Dpto. Anta, Salta, FML 02501, 06584, 06589; Misión La Paz, Dpto. Rivadavia, Salta, UNNEC 0176; Yuto, Dpto. Ledesma, Jujuy, FML 1084; Belén, Dpto. Belén, Catamarca (paratype of P. punctatus), FML 00015; Provincia de Misiones (paratype of P. punctatus), FML 00710; Campo Grande, Misiones (paratype of $P$. punctatus) [Located "Formosa", in error, by Lema (1979)], MACN (exCENAI 3310); Yacareí, Dpto. Itatí, Corrientes, UNNEC 0315. BRAZIL: Município de Ribas do Rio Pardo, Estado do Mato Grosso do Sul, AC 431, 432. PARAGUAY: Faro Moro, Dpto. Chaco, 60 km N Tte. Montanía, MACN 31975. 